Acta Theriologica 38 (4), $443-450,1993$.

PL ISSN 0001 - 7051

\title{
Antler conformation in red deer of the Mesola Wood, northern Italy
}

\author{
Stefano MATTIOLI
}

Mattioli S. 1993. Antler conformation in red deer of the Mesola Wood, northern Italy. Acta theriol. 38: $443-450$.

Red deer Cervus elaphus Linnaeus, 1758 stags from the Mesola Wood (northern Italy) are known for the very simplified structure of their antlers. An analysis was made of 180 sets of cranial appendages on 41 different individuals observed over 10 years. Considering only stags 5 years and older, the mean number of tines per antler pair was 5.36. The maximum number of tines per beam was invariably 4 : the bez tine and the crown were always absent. Yearlings and subadults exhibited scarcely developed cranial appendages, with a high incidence of knobbers and spikers respectively. While the poor performance of young classes may be mainly due to malnutrition, in adult stags a genetic component may prevail over dietary factors: selective shooting, inbreeding and genetic drift could have fixed the already simple design of their antlers.

Department of Evolutionary Biology, Ethology and Behavioural Ecology Group, University of Siena, Via P. A. Mattioli 4, 53100 Siena, Italy

Key words: Cervus elaphus, antler conformation, Italy

\section{Introduction}

The only native red deer Cervus elaphus Linnaeus, 1758 of the Italian peninsula live in the "Gran Bosco della Mesola" Natural Reserve; this population, isolated for centuries, was protected from persecutions by the neighbouring large marshes (Mattioli 1990). Local stags are known for their simple antler design (Castelli 1941, Perco 1984, Mattioli 1990). Cervid antlers are particularly sensitive to external and internal influences, but the relative importance of diet and heredity remains speculative (Goss 1983). Here I provide qualitative and quantitative data on the morphology of the cranial appendages of Mesola stags and discuss on the origin of their peculiarly poor quality, evaluating the potential role of nutritional and genetic factors.

\section{Study area and methods}

The Gran Bosco della Mesola is situated in northern Italy, in the Po delta area $\left(44^{\circ} 51^{\prime} \mathrm{N}, 12^{\circ} 15^{\prime} \mathrm{E}\right)$. Of its 1058 ha (110 inaccessible to ungulates), woods account for $87 \%$, with Quercus ilex predominant (Piccoli et al. 1983). The soil is sandy. Annual rainfall averages about $650 \mathrm{~mm}$. The majority of red deer live in the fenced area of Elciola (97 ha, including $68 \%$ of woodland and $16.5 \%$ of grassland). I 
analysed the characteristics of 180 sets of frontal appendages belonging to 41 different individuals from the Elciola enclosure. An annual population of $15-25$ stags $\geq 1$ year old was followed from 1982 to 1989 . During the 1990 - 1991 period, after the translocation of some adults, monitoring was continued for $6-7$ animals aged $1-4$ years. The cranial appendages were documented by photos and sketches, noting the number and type of points $\geq 2 \mathrm{~cm}$ (tines). Animals allowed observers to approach by car as close as $10-15 \mathrm{~m}$. The age was determined exactly for those stags marked as calves $(n=$ $10)$; for other individuals $(n=31)$ only an estimate of age was possible, based mainly on tooth eruption, replacement and wear patterns observed during capture (Wagenknecht 1984). Ageing live animals is necessarily approximate, so stags $>1$ year old were then mostly pooled into 3 age classes (subadults 2-4 years old, adults $5-9$ years old and adults 10 years and older). Besides ear tags and ear notches, individual recognition was also based on skin scars and coat colour patterns. Four sets of abnormal antlers were excluded.

One-way ANOVA was used to test for differences among years in number of antler tines: the raw data were square-root transformed (Sokal and Rohlf 1981). Differences between other means were examined using Student's $t$-test.

\section{Results}

In antlered stags $\geq 2$ years old from 1982 to 1989 , the mean number of tines per antler pair was $5.01(n=143)$. Considering only stags 5 years and older, the mean number of tines was $5.36(n=124$; Table 1$)$. No differences were found among years for number of tines $\left(\mathrm{F}_{7,116}=1.68, p=0.12\right)$. Mean values for stags $5-9$ and $\geq 10$ years old were respectively $4.59(n=56)$ and $5.99(n=68)$ tines per antler pair; the difference between these age classes was highly significant $(t=5.82, \mathrm{df}=122, p<0.001)$. In adult stags beams with three tines prevailed, with an incidence of $41.5 \%$; but sometimes simple unbranched spikes were also present, with a frequency of $10.7 \%$ in stags $5-9$ years old (Fig. 1). The maximum number of tines per beam was never more than 4 : the brow tine, the trez tine and the terminal fork. The bez tine and the crown were always missing. The fork did not occur before 10 years of age and then only infrequently: in stags 10 years and

Table 1. Mean number of points per antler pair in adult red deer stags $\geq 5$ years old from the Mesola Wood in period $1982-1989$.

\begin{tabular}{llll}
\hline Year & $\bar{x}$ & SD & $n$ \\
\hline 1982 & 4.94 & 1.06 & 16 \\
1983 & 5.77 & 1.25 & 17 \\
1984 & 5.17 & 1.04 & 18 \\
1985 & 6.00 & 1.62 & 17 \\
1986 & 4.67 & 1.68 & 18 \\
1987 & 5.07 & 1.67 & 15 \\
1988 & 5.75 & 1.91 & 12 \\
1989 & 5.73 & 1.35 & 11 \\
Total & 5.36 & 1.49 & 124 \\
\hline
\end{tabular}




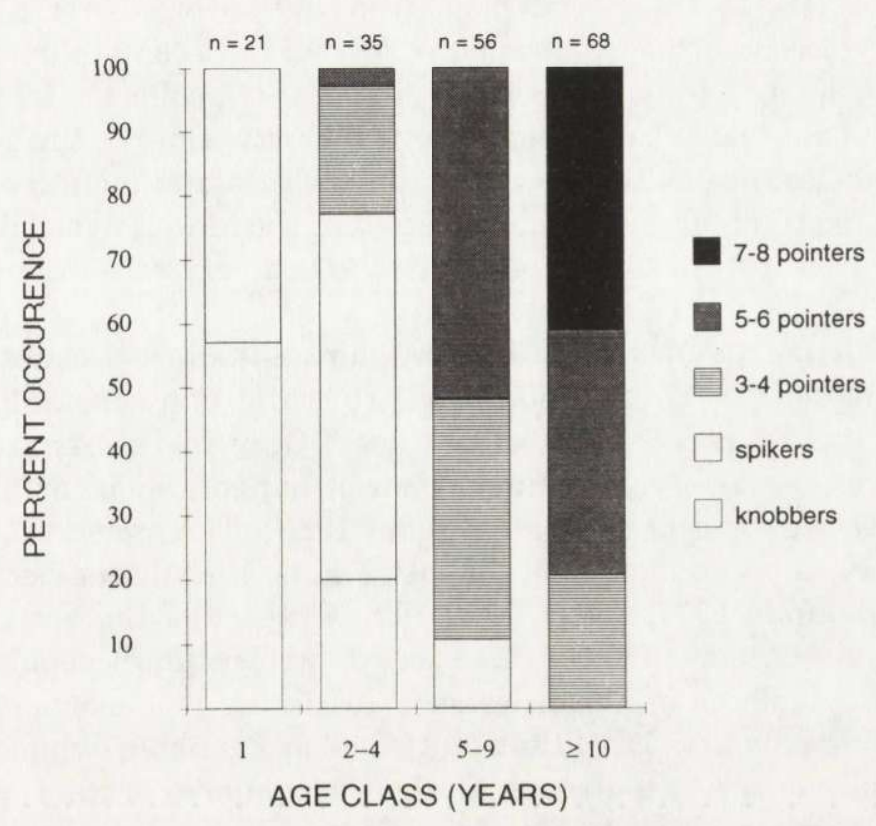

Fig. 1. Red deer stags classified according to point and age classes from the Mesola Wood in period 1982 - 1991.

older only $28.7 \%$ of beams had 4 tines and only $16.2 \%$ of antler pairs had 8 total tines. Only 4 different individuals were able to bear a total of 8 tines at least once in the study period (see Mattioli 1990 for representative antler types).

The first set of true antlers occurred at $1-4$ years of age. During the 10-year study, of 44 stags $1-3$ years old, $19(43.2 \%)$ were antlerless. Of 21 yearlings, 12 (57.1\%) failed to develop antlers; these stags normally delayed the growth of the pedicle until 14 - 16 months; in two cases the pedicles did not begin to develop until 20 months. When antlered, yearlings had two very short spikes, the pedicles being visible at $11-13$ months of age. Of 15 stags 2 years old, 5 were knobbers, only with fur-covered pedicles or with pedicles and tiny bone buttons. Of 9 stags 3 years old, 2 were knobbers with buttons. 'Hummels', i.e. antlerless adults with under-developed pedicles, did not occur.

\section{Discussion}

This very simplified antler structure was not an exclusive characteristic of the Elciola population during the years of study. The other sub-population of stags (about 15 individuals), in the same period, had roughly the same antler configuration, with a predominance of $5-6$ pointers among adults. Also, the only stag reared in captivity had antlers with two and three tine beams as an adult (1980 - 1989). According to reserve personnel, the present antler conformation 
has invariably occurred for at least $30-35$ years: the only partial exception is represented by a basal fragment of beam just cast-off, collected in 1981, that had a short stump (snag) about $1 \mathrm{~cm}$ long above the brow tine, in the typical position of the bez tine. Antlers with a bez tine, and with a rudimentary three-pointed crown, were sometimes observed and collected in the Mesola Wood during the first decades of the century (Castelli 1941: 311); the last very rare examples date back to the $50 \mathrm{~s}$.

The complete lack of antlers with crown during the last decades is surprising, practically unique: the multi-pointed cup-like crown is a constant characteristic of all the European populations of red deer. Only in the Asiatic and North-American forms is it very uncommon (maral, hangul, shou) or absent (wapiti) (Geist 1971, Groves and Grubb 1987, Dolan 1988). The crown originated in the early Middle Pleistocene and since the late Middle Pleistocene became a regular antler trait (Beninde 1937, Lister 1987). The absence of the bez tine is equally peculiar; it is an exclusive tine of this species, present in all populations, though not in all individuals or in all antler sets. According to Isakovic (1969) the bez tine was missing only in $5.5 \%$ of the adult stags in Pannonia, while it was lacking in $28.5 \%$ of cases in the Carpathians. In the German area of the Harz Mountains, which is sufficiently representative of the Central Europe condition, the bez tine occurred in about half the stags $8-14$ years old during the $80 \mathrm{~s}(\mathrm{H}$. Drechsler, pers. comm. 1989).

Typically, a fully mature European stag has antlers with $10-12$ total tines (Drechsler 1980, Langvatn 1986). The three-tined beam already occurs at 2 years of age and the four tine condition is typical of stags 4 years old (Reulecke 1987). Even the modest antlers of deer from the Scottish Highlands and Sardinia are on average less simplified and more variable than those of the Mesola Wood (Lowe 1971, Mitchell et al. 1986; Beccu 1989, S. Mattioli, pers. obs. 1990). And yet, the Scottish and Sardinian red deer are quite similar to the Mesola deer in body size. At Glenfeshie (Scotland) adult stags sampled had a mean live weight of $115 \mathrm{~kg}$, a mean antler mass of $1.2 \mathrm{~kg}$, and a mean tine number of 6.6 (range $0-14$ ) (Mitchell et al. 1986). Adult stags shot at Rhum (Scotland) in 1957 - 1965 had the same mean body weight, with an antler mass averaging about $1.35 \mathrm{~kg}$; they were mainly $8-9$ pointers, but tine number ranged from 0 to 16 (V. P. W. Lowe, pers. comm. 1986). In Sardinia adult stags weigh $100-120 \mathrm{~kg}$ and have a number of antler tines ranging from 0 to 12 (Beccu 1989). Adult stags from Mesola weigh on average about $110 \mathrm{~kg}$, are typically 5 or 6 pointers bearing antlers of $0.9 \mathrm{~kg}$; at 10 or more years of age, they reach a body weight of about $120-125 \mathrm{~kg}$, are on average 6 pointers, and have a mean antler mass of $1.25 \mathrm{~kg}(\mathrm{SD}=0.36$, $n=23$ ) (Mattioli 1990 and unpubl.).

Only the antlers of the extinct Corsican red deer may have had an equally simplified construction (Vigne and Marinval-Vigne 1988): but this may be an artifact due to the limited sample available, as suggested by a comparison with the similar Sardinian red deer antlers (S. Mattioli, pers. obs. 1990). 
Antlers, like other secondary sexual characters, have low growth priority and are strongly affected by ecological factors: their growth and dimensions are influenced by food quality and availability (Vogt 1947, Goss 1983, Brown 1990). Antler size varies in response to periodic environmental fluctuations (Anderson 1981, Rasmussen 1985, Schmid 1990). Colonizing populations in high quality habitats ('dispersal phenotypes', sensu Geist 1987) display rapid body growth, but also relatively large antlers (McCorquodale et al. 1989). Resource-restricted populations in environments with poor forage and/or at high density ('maintenance phenotypes' of Geist 1987), show, together with a low reproductive performance and modest body size, scarcely developed antlers (e.g. Scotland, Sardinia and North Africa). Antler dimensions are often used as a 'condition index' of cervid populations (Anderson and Medin 1969, Rasmussen 1985, McCorquodale et al. 1989, Brown 1990).

High population density tends to delay antler development, resulting in a high proportion of knobbers among yearlings (Clutton-Brock et al. 1982, Mitchell et al. 1986). Pedicle initiation is associated with a threshold body weight and the development of the first antler set is only possible when the pedicle reaches a critical length (Suttie and Kay 1983, Fennessy and Suttie 1985). Dietary deficiencies during foetal growth or early life can condition the maturation of the endocrine system, with marked effects on pedicle and antler development of young stags ('retarded' deer of Bubenik 1983). Stags characterized by delayed maturation are occasionally unable to compensate in adult age for initial disadvantages: the 'hummel' phenomenon, occurring in marginal and impoverished habitats, seems to be a case (Lincoln and Fletcher 1984). The poorly developed cranial appendages of yearlings and subadults from the Mesola Wood may be primarily due to undernutrition. During the study period, this red deer population clearly suffered the effects of high density and inter-specific competition (around 6,700-10,200 kg of ungulate biomass per sq $\mathrm{km}$ ), with reduced body weights, attenuated sexual dimorphism, delayed puberty, low calving rate and post-winter recruitment (Mattioli 1990, 1993). But as noted above, the current antler design has been present in the Mesola Wood for decades, even when the density was much lower (1950 - 1970: perhaps $1-4$ red deer plus $0-21$ fallow deer per sq $\mathrm{km}$, equivalent to about $70-1,200$ $\mathrm{kg}$ of biomass per $\mathrm{sq} \mathrm{km}$ ). This suggests a possible role for genetic factors, which in adult stags could prevail over nutritional effects. Body size and antler characters have been related to genetic variability; high levels of heterozygosity in white-tailed deer Odocoileus virginianus from Savannah River Plant corresponded to greater body mass, antler length and number of tines (Scribner et al. 1989, Scribner and Smith 1990). Hartl et al. (1991) failed to detect any association between heterozygosity and antler features in red deer, but they found a relationship between certain genotypes and morphological characters of antlers; they also documented an influence of selective hunting on allele frequencies at genes associated with physical traits used as selection criteria. 
Hunting (legal until the 1940s) and poaching, deliberately removing the best 'trophy' stags from Mesola Wood (Castelli 1941: 312), may have affected the gene pool of the small population of red deer. Moreover this relict nucleus of animals is heavily inbred; in 1945 - 1947 perhaps only 10 survived and the sub-population of the Elciola enclosure originated in 1972 from probably 12 founders. The founder principle has been proposed to explain the simple antler shape in two different populations of sika deer Cervus nippon (Feldhamer et al. 1985, Kaji et al. 1988); the same effect was suggested for high quality antlers of white-tailed deer from George Reserve (McCullough 1982). The Mesola red deer, segregated for centuries in a restricted and relatively unproductive area, probably has been represented for long periods by maintenance phenotypes, with animals of reduced stature and poorly antlered stags; 'trophy'-oriented shooting, genetic bottlenecks and inbreeding may have 'crystallized' the already simple antler architecture. In order to fully understand the potential of the Mesola red deer and verify to what extent the current antler traits are reversible, it is essential to remove as far as possible the present disturbing factors (lowering density, eliminating other ungulates and improving the quality of pasture) and to start a genetical screening and controlled breeding programs.

Acknowledgements: I thank N. Chapman, R. Dzięciołowski, M. Festa-Bianchet and S. Lovari for critically reading earlier versions of the manuscript. Two anonymous reviewers provided useful comments.

\section{References}

Anderson A. E. 1981. Morphological and physiological characteristics. [In: Mule and black-tailed deer of North America. O. C. Wallmo, ed]. University of Nebraska Press, Lincoln: 27 - 97.

Anderson A. E. and Medin D. E. 1969. Antler morphology in a Colorado mule deer population. J. Wildl. Manage. 36: $579-594$.

Beccu E. 1989. Il cervo sardo. Delfino Editore, Sassari: 1 - 167.

Beninde J. 1937. Zur Naturgeschichte des Rothirsches. Schoeps Verlag, Leipzig: $1-224$.

Brown R. D. 1990. Nutrition and antler development. [In: Horns, pronghorns, and antlers. G. A. Bubenik and A. B. Bubenik, eds]. Springer Verlag, New York: $426-441$.

Bubenik A. B. 1983. Proposals for standardized nomenclature for bony appendices in Pecora. [In: Antler development in Cervidae. R. D. Brown, ed]. Caesar Kleberg Wildlife Institute, Kingsville: $187-194$.

Castelli G. 1941. Il cervo europeo. Olimpia, Firenze: 1 - 393.

Clutton-Brock T. H., Guinness F. E. and Albon S. D. 1982. Red deer: behavior and ecology of two sexes. Univ. of Chicago Press, Chicago: $1-378$.

Dolan J. M. 1988. A deer of many lands: a guide to the subspecies of the red deer Cervus elaphus. Zoonooz 62 (10): 4 - 34 .

Drechsler H. 1980. Über die Geweihbildung bei Rothirschen im "Rotwildring Harz" in den Jahren 1959 - 1978. Z. Jagdwiss. 26: $207-219$.

Feldhamer G. A., Stauffer J. R. and Chapman J. A. 1985. Body morphology and weight relationships of sika deer in Maryland. Z. Säugetierk. 50: 88 - 106.

Fennessy P. F. and Suttie J. M. 1985. Antler growth: nutritional and endocrine factors. [In: Biology of deer production. P. F. Fennessy and K. R. Drew, eds]. Royal Society of New Zealand, Wellington: $239-250$. 
Geist V. 1971. On the relation of the social evolution and dispersal in ungulates during the Pleistocene, with emphasis on the Old World deer and the genus Bison. Quaternary Res. 1: $283-315$.

Geist V. 1987. On the evolution of optical signals in deer. A preliminary analysis. [In: Biology and management of the Cervidae. C. M. Wemmer, ed]. Smithsonian Institution Press, Washington: $235-255$.

Goss R. J. 1983. Deer antlers. Regeneration, function and evolution. Academic Press, New York: $1-316$.

Groves C. P. and Grubb P. 1987. Relationships of living Cervidae. [In: Biology and management of Cervidae. C. M. Wemmer, ed]. Smithsonian Institution Press, Washington: $21-59$.

Hartl G. B., Lang G., Klein F. and Willing R. 1991. Relationships between allozymes, heterozygosity and morphological characters in red deer (Cervus elaphus), and the influence of selective hunting on allele frequency distributions. Heredity $66: 343-350$.

Isakovic I. 1969. Morfologija jelenjih parogova Belja. Jelen 8: 5 - 59.

Kaji K., Koizumi T. and Ohtaishi N. 1988. Effects of resources limitation on the physical and reproductive condition of sika deer on Nakanoshima Island, Hokkaido. Acta theriol. 33: 187 - 208.

Langvatn R. 1986. Size and weight relationships in Norwegian red deer (Cervus elaphus atlanticus). [In: Das Rotwild - Cerf rouge - Red deer. H. Reuss, ed]. Proc. C.I.C. Symp., Graz: $244-266$.

Lincoln G. A. and Fletcher J. 1984. History of a hummel: nature vs nurture. Deer 6: $127-131$.

Lister A. M. 1987. Diversity and evolution of antler form in Quaternary deer. [In: Biology and management of Cervidae. C. M. Wemmer, ed]. Smithsonian Institution Press, Washington: 81 - 98.

Lowe V. P. W. 1971. Some effects of a change in estate management on a deer population. [In: The scientific management of animal and plant communities for conservation. E. A. Duffey and A. S. Watt, eds]. Blackwell, Oxford: $435-456$.

Mattioli S. 1990. Red deer in the Italian peninsula, with particular reference to the Po delta population. Deer 8 (2): $95-98$.

Mattioli S. 1993. Basso rendimento riproduttivo in una popolazione di cervi. Suppl. Ric. Biol. Selv. (Bologna) 21: 535 - 539. [In Italian with English summary]

McCorquodale S. M., Eberhardt L. E. and Sargeant G. A. 1989. Antler characteristics in a colonizing elk population. J. Wildl. Manage. 53: $618-621$.

McCullough D. R. 1982. Antler characteristics of George Reserve white-tailed deer. J. Wildl. Manage. 46: $821-826$.

Mitchell B., McCowan D. and Parish T. 1986. Performance and population dynamics in relation to management of red deer at Glenfeshie. Biol. Conserv. 37: 237 - 267.

Perco F. 1984. Ricerca sui Cervidi. [In: Riserva Naturale Gran Bosco della Mesola: piano di gestione faunistica per il decennio 1980 - 1989. B. Minerbi, ed]. Min. Agric. For., Roma: $107-165$.

Piccoli F., Gerdol R. and Ferrari C. 1983. Carta della vegetazione del Bosco della Mesola (Ferrara). Atti Ist. Bot. e Lab. Critt. 2: 3-23.

Rasmussen G. P. 1985. Antler measurements as an index to physical condition and range quality with respect to white-tailed deer. N. Y. Fish Game J. 32: 97 - 113.

Reulecke K. 1987. Zur Geweihentwicklung der Hirsche im Harz. Wild u. Hund 24/87: $41-45$.

Schmid P. 1990. Zum Einfluss der Witterung auf die jährlichen Schwankungen der Geweihstärke beim Rothirsch (Cervus elaphus) im Oberwallis (Schweizer Alpen). Jahrb. Naturhist. Mus. Bern 10: $141-150$.

Scribner K. T. and Smith M. H. 1990. Genetic variability and antler development. [In: Horns, pronghorns, and antlers. G. A. Bubenik and A. B. Bubenik, eds]. Springer-Verlag, New York: $460-473$.

Scribner K. T., Smith M. H. and Johns P. E. 1989. Environmental and genetic components of antler growth in white-tailed deer. J. Mammal. 70: $284-291$.

Sokal R. R. and Rohlf F. 1981. Biometry. Freeman, New York: $1-859$.

Suttie J. M. and Kay R. N. B. 1983. The influence of nutrition and photoperiod on the growth of antlers of young red deer. [In: Antler development in Cervidae. R. D. Brown, ed]. Caesar Kleberg Wildlife Research Institute, Kingsville: $61-71$. 
Vigne J.-D. and Marinval-Vigne M.-Ch. 1988. Contribution a la connaissance du cerf de Corse (Cervus elaphus, Artiodactyla, Mammalia) et de son histoire. Bull. Ecol. 19: 177 - 187.

Vogt F. 1947. Das Rotwild. Oesterr. Jagd- und Fischereiverlag, Wien: 1-208.

Wagenknecht E., ed 1984. Die Altersbestimmung des erlegten Wildes. Neumann-Neudamm, Melsungen: $1-148$.

Received 3 February 1993, accepted 5 August 1993. 